\title{
Comparative Effects of Glucocorticoids and Prostaglandins on Small Intestine of Infant Rats
}

\author{
JOSEF NEU, WENDELL N. CRIM, AND NANCY C. HODGE \\ Division of Neonatology, Department of Pediatrics, J. Hillis Miller Health Center, University of Florida College \\ of Medicine, Gainesville, Florida 32610
}

\begin{abstract}
Previous studies have suggested similarities between the effects of exogenously administered glucocorticoids and prostaglandins in the developing rat small intestine. In this study the effects of exogenously administered glucocorticoids and prostaglandins were compared. In addition, the effects of prostaglandins in adrenalectomized rats were evaluated. Members of both classes of compounds stimulate small intestinal disaccharidase activities, and increase RNA to DNA ratio and brush border membrane protein synthesis. Hydrocortisone accelerates enterocyte turnover, whereas prostacyclin does not. Enteral administration of 16,16-dimethyl prostaglandin $E_{2}$ stimulates disaccharidase activities in intact as well as shamoperated and adrenalectomized animals. The data suggest that certain prostaglandins may play a role in small intestinal metabolism which is similar to that of the glucocorticoids but is independent of the adrenal-intestinal axis. (Pediatr Res 20: 109-112, 1986)
\end{abstract}

\section{Abbreviations}

PG, prostaglandin

16,16-DMPGE 2 , 16,16-dimethyl PGE

Glucocorticoids are known to play a significant role in the development of small intestinal biochemical function. These hormones appear to mediate a series of enzymatic changes in the small intestine of rats during the 3rd wk of postnatal life (13). Administration of hydrocortisone or ACTH during the 2 nd postnatal wk causes precocious appearance of sucrase activity (4), whereas adrenalectomy at this time markedly slows the usual increase of sucrase activity (5). In adult rats, sucrase activity is independent of glucocorticoids (6).

In a previous study by our group (7), prostaglandins were administered to suckling rats to determine their effects on growth and development. Analysis of small intestinal hydrolase activities demonstrated effects similar to those of the glucocorticoids. Other than this, little information is available regarding the physiological role of prostaglandins in the gastrointestinal tract of the developing fetus and neonate. More recent studies by Koelz et al. (8) have demonstrated that an enterally administered prostaglandin analog, 16,16-DMPGE 2 , will stimulate disaccharidase activity in the small intestine of suckling but not adult rats.

Since the stimulation of the enzyme activities by the glucocorticoids and prostaglandins are similar in many respects, we decided to investigate further the comparative effects of these two classes of compounds. The purpose of these studies was

Received June 24. 1985: accepted September 12, 1985

Address correspondence and reprint requests to Josef Neu. M.D.. Department of Pcdiatrics. Box J-296.J. Hillis Miller Health Center, University of Florida College of Medicine. Gainesville, FL 32610. twofold: 1) to compare the effects of glucocorticoids and prostaglandins in terms of disaccharidase activities, nucleic acid ratio, brush border protein synthesis, and DNA synthesis; and 2) to determine the effects of prostaglandins on small intestinal disaccharidases in intact and adrenalectomized suckling rats. Rats were adrenalectomized in order to determine whether prostaglandins directly affect the intestine or whether these effects occur as a result of stimulation of the adrenal glands.

\section{MATERIALS AND METHODS}

Animals. Infant Sprague-Dawley rats were used in this study. They were caged with their mothers and allowed to suckle ad libitum in a temperature and light-controlled environment.

Chemicals and reagents. Cellobiose and lactose were purchased from Calbiochem (La Jolla, CA), sucrose from Mallinckrodt, Inc. (Paris, KY), maltose from Sigma Chemical Company (St. Louis, MO), and Statzyme glucose $500 \mathrm{~nm}$ from Worthington (Freehold, New Jersey). Prostacyclin $\left(\mathrm{PGI}_{2}\right)$ and 16,16-DMPGE were obtained from the Upjohn Company (Kalamazoo, MI). Reagent grades of DNA (calf thymus type 1) and RNA (torula yeast type 6) were obtained from Sigma Chemical Company (St. Louis, MO). Bovine serum albumin was obtained from Eastman (Rochester, NY). Corticosterone ${ }^{3} \mathrm{H}$ kits were obtained from Radioassay Systems Laboratories, Inc. (Carson, CA; catalogue no 301$).{ }^{3} \mathrm{H}$-leucine $(40-60 \mathrm{Ci} / \mathrm{mmol})$ was obtained from New England Nuclear. Hydrocortisone sodium succinate $(100 \mathrm{mg} / 2$ ml) was obtained from Abbott Laboratories (North Chicago, IL).

Experimental design. One group of studies was done in order to compare the relative effects of subcutaneously administered prostacyclin to hydrocortisone. Another group of studies was done to determine the effects of enterally administered $16,16-$ $\mathrm{DMPGE}_{2}$ on intact and adrenalectomized rats. For the studies designed to compare intestinal hydrolase activities, enterocyte turnover time, and brush border membrane disaccharidase synthesis after parenteral administration of prostacyclin or hydrocortisone, three sets of suckling littermates were treated with 0.3 $\mathrm{mg} / \mathrm{kg} \mathrm{PGI} 2,50 \mathrm{mg} / \mathrm{kg}$ hydrocortisone or $0.9 \%$ saline three times a day by subcutaneous injection in $50 \mu \mathrm{l}$ volumes. Injections were given subcutaneously in the neck and aimed caudally to eliminate leakage of injectate. In order to insure that $\mathrm{PGI}_{2}$ was injected in an active form, it was prepared shortly before the injection in $0.0103 \mathrm{M}$ mannitol, $0.25 \mathrm{M} \mathrm{NaCl}, 0.333 \mathrm{M}$ glycine, and $\mathrm{pH} 10.5$ buffer. The first set, containing two animals per group, received $15 \mu \mathrm{Ci}{ }^{3} \mathrm{H}$-thymidine at 18,36 , and $72 \mathrm{~h}$ before sacrifice in order to measure cell turnover rate from crypt to villus. A second set of animals was given prostacyclin, hydrocortisone, or saline for studies of DNA synthesis rate. In a third set of animals, ${ }^{3} \mathrm{H}$-leucine was administered $18 \mathrm{~h}$ before sacrifice to determine protein synthesis. On day 14 of life, these animals were sacrificed by decapitation between 0800 and $1100 \mathrm{~h}$ in all studies to eliminate any diurnal effects on intestinal disaccharidase activities. Disaccharidase activity and protein were meas- 
ured and DNA and RNA were assayed in the total remaining small intestine (duodenum to distal ileum) of all animals.

For the studies designed to determine the effects of enteral prostaglandins, 16,16-DMPGE 2 was administered at a dose of $100 \mu \mathrm{g} / \mathrm{kg}$ twice daily to intact rats on days 9 to 13 . These animals were sacrificed on day 14. Triacitin, the 16,16-DMPGE vehicle, was administered to control rats. Adrenalectomized or sham-operated littermates were also gavaged with a volume of $50 \mu \mathrm{l}$ of $16,16-\mathrm{DMPGE}_{2}(100 \mu \mathrm{g} / \mathrm{kg})$ or Triacitin. For the studies comparing adrenalectomized to sham-operated rats, surgery was performed on day 10 of life. These animals were sacrificed on day 15. Adrenalectomy was done on day 10 by a posterior approach under methoxyfluorane anesthesia. Sham-operated animals had their kidney and adrenals manipulated but without removal of the adrenal glands. Trunk blood was collected at the time of sacrifice for corticosterone radioimmunoassay in order to validate completeness of adrenalectomy. Adrenalectomy was considered complete only if no adrenal tissue could be seen at autopsy examination and if the blood corticosterone levels were significantly lower than in the nonadrenalectomized rats.

Analyses. Rats were weighed daily to determine the increase in total body weight. Immediately after sacrifice, the small intestines were gently flushed with cold saline and weighed. In rats in which only homogenate intestinal enzyme activity and nucleic acids and proteins were to be measured, the small intestines were homogenized 1:5 (intestinal weight:volume of buffer) in $10 \mathrm{mM}$ sodium phosphate buffer, $\mathrm{pH} 6.0,0.002 \%$ Triton $\mathrm{X}-100$ for biochemical analyses. Fresh homogenate was precipitated in 0.4 $\mathrm{N}$ perchloric acid ( $1: 3 \mathrm{v}: \mathrm{v})$ for protein assay.

Disaccharidase activities were assayed at $37^{\circ} \mathrm{C}$ in $250 \mu \mathrm{l}$ reaction volume in $50 \mathrm{mM}$ sodium phosphate buffer, $\mathrm{pH} 6.0$, using $0.04 \mathrm{M}$ sucrose (for sucrase activity), $0.0156 \mathrm{M}$ maltose (glucoamylase activity), and $0.0156 \mathrm{M}$ cellobiose or $0.188 \mathrm{M}$ lactose for measuring of lactase activity as described by Tsuboi et al. (9). Disaccharidase activity was expressed as mmol substrate per min per total small intestine (total enzyme activity). Specific activity was expressed as total enzyme activity per milligram of protein or per milligram of DNA. Protein was measured by the method of Lowry et al. (10). DNA was measured by the method of Burton (11) and RNA as described by Munro and Fleck (12). Corticosterone radioimmunoassay was done as described by the manufacturers of the corticosterone ${ }^{3} \mathrm{H}$ kit (13). For the brush

Table 1. Wt changes for rat littermates given parenteral prostacyclin, hydrocortisone, or saline $(\bar{x} \pm S D)$

\begin{tabular}{ccc}
\hline & \multicolumn{2}{c}{ Animal wt $(\mathrm{g})$} \\
\cline { 2 - 3 } Treatment & $\begin{array}{c}10 \text { days old } \\
(n=6)\end{array}$ & $\begin{array}{c}14 \text { days old } \\
(n=6)\end{array}$ \\
\hline $\mathrm{PGI}_{2}$ & $18.1 \pm 0.7$ & $21.8 \pm 1.2^{*}$ \\
Hydrocortisone & $17.1 \pm 0.8$ & $20.0 \pm 1.4 \dagger$ \\
Saline & $17.9 \pm 0.8$ & $24.0 \pm 1.3$ \\
\hline
\end{tabular}

$p$ values vs saline control group: ${ }^{*} p<0.02 ; \dagger p<0.001$. border membrane preparation and protein synthesis studies, an aliquot of the 1:5 (w:v) homogenate was diluted 1:20 (v:v). Brush border membranes were then prepared by the calcium chloride precipitation technique of Schmitz et al. (14) without the gradient centrifugation steps. Only membranes with a 5-fold or greater increase in lactase-specific activity per $\mathrm{mg}$ of protein from intestinal homogenate to brush border membrane were used for the protein synthesis studies. ${ }^{3} \mathrm{H}$-leucine incorporation was measured using liquid scintillation counting of cpm homogenate and brush border membrane protein precipitated by $0.4 \mathrm{~N}$ PCA. DNA synthesis was measured by the method of Johnson and Guthrie (15). Enterocyte turnover was measured as described by Tsuboi et al. (16). Statistical analyses were done using a one-way analysis of variance as an overall comparison of all groups (prostacyclin, hydrocortisone-, or saline-treated). Individual comparisons were made by either the least significant differences procedure in the animals comparing prostacyclin, hydrocortisone or saline treatment and Student's $t$ test in the studies where 16,16$\mathrm{DMPGE}_{2}$ was compared to Triacitin treatment.

\section{RESULTS}

Representative weight changes for the suckling rat littermates that were given prostacyclin, hydrocortisone, or saline subcutaneously are shown in Table 1 . The animals given hydrocortisone or prostacyclin showed a slower growth rate than did either the

Table 3. Comparison of small intestinal disaccharide activities after parenteral prostacyclin or hydrocortisone treatment in suckling rats ( $\mu$ mol/substrate utilized/min; $\bar{x} \pm S D$ )

\begin{tabular}{cccc}
\hline & \multicolumn{3}{c}{ Treatment } \\
\cline { 2 - 4 } & $\mathrm{PGI}_{2}$ & Hydrocortisone & Control (saline) \\
\hline Total lactase & $1.62 \pm 0.33^{*}$ & $0.94 \pm 0.22$ & $1.07 \pm 0.09$ \\
& $(6)$ & $(6)$ & $(4)$ \\
Lactase per mg & $0.023 \pm 0.003 \dagger$ & $0.014 \pm 0.002$ & $0.015 \pm 0.002$ \\
protein & $(6)$ & $(6)$ & $(4)$ \\
Lactase per mg & $0.517 \pm 0.062 \ddagger$ & $0.626 \pm 0.0141 \ddagger$ & $0.311 \pm 0.06$ \\
DNA & $(9)$ & $(9)$ & $(10)$ \\
Total sucrase & $0.48 \pm 0.24 \dagger$ & $2.98 \pm 0.24 \ddagger$ & $0.04 \pm 0.02$ \\
& $(6)$ & $(6)$ & $(4)$ \\
Sucrase per mg & $0.008 \pm 0.004 *$ & $0.045 \pm 0.005 \ddagger$ & $0.001 \pm 0.001$ \\
protein & $(6)$ & $(6)$ & $(4)$ \\
Sucrase per mg & $0.118 \pm 0.091 \dagger$ & $1.040 \pm 0.330 \ddagger$ & $0.015 \pm 0.032$ \\
DNA & $(9)$ & $(9)$ & $(10)$ \\
Total maltase & $5.0 \pm 1.9 \ddagger$ & $19.9 \pm 3.7 \ddagger$ & $0.7 \pm 0.5$ \\
& $(6)$ & $(6)$ & $(6)$ \\
Maltase per mg & $0.074 \pm 0.032 \dagger$ & $0.297 \pm 0.020 \ddagger$ & $0.010 \pm 0.007$ \\
protein & $(6)$ & $(6)$ & $(6)$ \\
Maltase per mg & $1.45 \pm 0.33 \ddagger$ & $11.08 \pm 4.20 \ddagger$ & $0.48 \pm 0.37$ \\
DNA & $(6)$ & $(9)$ & $(10)$ \\
\hline Not &
\end{tabular}

Numbers in parentheses indicates number of rats.

$P$ values vs saline control group: ${ }^{*} p<0.02 ; \dagger p<0.01 ; \ddagger p<0.001$.

Table 2. Total small intestinal variables in rats given parenteral prostacyclin, hydrocortisone, or saline $(\bar{x} \pm S D)$

\begin{tabular}{|c|c|c|c|c|c|c|}
\hline \multirow[b]{2}{*}{ Treatment } & \multicolumn{3}{|c|}{ Total small intestine } & \multirow[b]{2}{*}{$\frac{\mathrm{RNA}}{\mathrm{DNA}}$} & \multirow{2}{*}{$\begin{array}{c}{ }^{3} \mathrm{H} \text {-thymidine incorporation } \\
\text { into small intestinal } \\
\text { homogenate } \\
\left({ }^{3} \mathrm{H} \mathrm{cpm} / \mathrm{mg} \mathrm{DNA}\right)\end{array}$} & \multirow{2}{*}{$\begin{array}{l}{ }^{3} \mathrm{H} \text {-leucine incorporation into } \\
\text { brush border membrane protein } \\
\text { (cpm/mg membrane protein) } \\
\text { (cpm/mg total intestine protein) }\end{array}$} \\
\hline & Protein (mg) & DNA (mg) & RNA (mg) & & & \\
\hline $\mathrm{PGI}_{2}$ & $\begin{array}{c}83 \pm 20 \\
(28)\end{array}$ & $\begin{array}{c}12.0 \pm 1.3 \\
(11)\end{array}$ & $\begin{array}{c}4.03 \pm 0.49 \\
(11)\end{array}$ & $\begin{array}{c}0.34 \pm 0.03 \dagger \\
\text { (11) }\end{array}$ & $14517 \pm 15087$ & $2.26 \pm 0.60 \dagger$ \\
\hline Hydrocortisone & $\begin{array}{c}84.0 \pm 24 \\
(30)\end{array}$ & $\begin{array}{l}11.5 \pm 1.4^{*} \\
(12)\end{array}$ & $\begin{array}{c}4.69 \pm 0.56 \div \\
(12)\end{array}$ & $\begin{array}{c}0.41 \pm 0.03 \ddagger \\
(12)\end{array}$ & $\begin{array}{c}13947 \pm 9318 \\
(7)\end{array}$ & $\begin{array}{c}2.34 \pm 0.49 \dagger \\
(12)\end{array}$ \\
\hline Control (saline) & $\begin{array}{c}87 \pm 20 \\
(29)\end{array}$ & $\begin{array}{c}13.0 \pm 1.4 \\
(12) \\
\end{array}$ & $\begin{array}{c}3.90 \pm 0.35 \\
(12)\end{array}$ & $\begin{array}{c}0.30 \pm 0.02 \\
(12)\end{array}$ & $\begin{array}{c}7454 \pm 2342 \\
(8) \\
\end{array}$ & $\begin{array}{c}1.80 \pm 0.24 \\
(12) \\
\end{array}$ \\
\hline
\end{tabular}

Numbers in parentheses indicate numbers of rats.

$P$ values vs saline control group: ${ }^{*} p<0.05 ; \dagger p<0.025 ; \ddagger p<0.001$. 
saline-administered animals or animals not injected with drug or saline. No diarrhea was noticed in any group of animals. Table 2 shows that total small intestinal protein did not differ significantly among the groups of animals receiving prostacyclin, hydrocortisone, or saline. Total DNA per small intestine was slightly lower in the hydrocortisone-treated group. Total RNA was significantly higher in the hydrocortisone-treated group. The RNA:DNA ratio was elevated in the $\mathrm{PGI}_{2-}$ and hydrocortisonetreated groups. No significant differences were seen in DNA synthesis as measured by ${ }^{3} \mathrm{H}$-thymidine incorporation into DNA of the prostacyclin-treated, hydrocortisone-treated, or control animals. ${ }^{3} \mathrm{H}$-leucine incorporation as a measure of brush border membrane protein synthesis was normalized to ${ }^{3} \mathrm{H}$-leucine incorporation into total intestinal homogenate protein. The $\mathrm{PGI}_{2}$ and hydrocortisone treated animals had a higher ${ }^{3} \mathrm{H}$-leucine incorporation which reflects greater brush border membrane protein synthesis in $\mathrm{PGI}_{2}$ and hydrocortisone treated animals. Table 3 demonstrates significant elevations in the activities of sucrase and maltase with mild elevations in lactase after hydrocortisone or $\mathrm{PGI}_{2}$ administration. Table 4 compares cell turnover times after prostacyclin or hydrocortisone treatment. The rate of cell turnover from crypt to villus tip in the hydrocortisone-

Table 4. Enterocyte turnover after parenteral hydrocortisone or prostacyclin treatment*

\begin{tabular}{|c|c|c|c|}
\hline \multirow[b]{2}{*}{$\begin{array}{l}\text { Migration } \\
\quad(\mathrm{hr})\end{array}$} & \multicolumn{3}{|c|}{ Treatment } \\
\hline & \multicolumn{3}{|c|}{$\begin{array}{l}\text { (\% villus height migrated by }{ }^{3} \mathrm{H} \text {-labeled } \\
\text { enterocyte) }\end{array}$} \\
\hline 18 & 20 & 20 & 30 \\
\hline 36 & 30 & 20 & 50 \\
\hline 72 & 40 & 60 & $>100$ \\
\hline
\end{tabular}

* There were two rats in each group. administered animals was accelerated. By $72 \mathrm{~h}$, the radiolabeled enterocytes of the hydrocortisone-treated animals were already coming off the tip of the vilus, whereas in the prostacyclin-treated and control rats a level of only about $40-60 \%$ of villus height had been reached at $72 \mathrm{~h}$.

Table 5 shows the effects of enterally administered 16,16$\mathrm{DMPGE}_{2}$ on small intestine disaccharidase activities in nonoperated animals. The animals treated with 16,16-DMPGE ${ }_{2}$ had elevations of total sucrase and specific activity of sucrase per mg of protein. Maltase total units, specific activity per mg of protein and specific activity per mg of DNA were also high in prostaglandin-treated rats. Table 6 shows the effects of enteral 16,16$\mathrm{DMPGE}_{2}$ treatment on adrenalectomized and sham-operated animals. Blood corticosterone levels were significantly lower in the adrenalectomized rats when compared to the sham-operated rats. No differences were seen within the sham or adrenalectomized groups given prostaglandin or Triacitin. The sham-operated animals showed significant increases of total units of sucrase per $\mathrm{mg}$ of protein in addition to increases in maltase total units and maltase-specific activity per $\mathrm{mg}$ of protein. Similarly, adrenalectomized animals had significant elevations of sucrase total units and sucrase specific activity per mg of protein. In addition to significant elevations of maltase total units, there were slight increases of maltase-specific activity per $\mathrm{mg}$ of protein in the adrenalectomized prostaglandin-treated animals versus adrenalectomized control animals treated unly with Triacitin.

\section{DISCUSSION}

Several alterations in small intestine characteristics of suckling rats appear to be caused by $\mathrm{PGI}_{2}$ or hydrocortisone treatment. These include a slower growth rate, elevated RNA/DNA ratios, increased ${ }^{3} \mathrm{H}$-leucine incorporation into brush border membrane protein normalized to total homogenate protein, and increased disaccharidase activities. The increase in RNA/DNA ratio after glucocorticoid and $\mathrm{PGI}_{2}$ administration is difficult to interpret

Table 5. Effects of enterally administered 16,16-DMPGE $(100 \mu \mathrm{g} / \mathrm{kg})$ on small intestine disaccharidase activities in nonoperated rats; rats were sacrificed on day 14 of life $(\bar{x} \pm S D)$

\begin{tabular}{|c|c|c|c|c|c|c|}
\hline \multirow[b]{2}{*}{ Treatment } & \multicolumn{3}{|c|}{ Sucrase* } & \multicolumn{3}{|c|}{ Maltase } \\
\hline & Total units & $\begin{array}{l}\text { Specific activity } \\
\text { per mg protein }\end{array}$ & $\begin{array}{l}\text { Specific activity } \\
\text { per mg DNA }\end{array}$ & $\begin{array}{l}\text { Total } \\
\text { units }\end{array}$ & $\begin{array}{l}\text { Specific activity } \\
\text { per mg protein }\end{array}$ & $\begin{array}{c}\text { Specific activity } \\
\text { per mg DNA }\end{array}$ \\
\hline $16,16-\mathrm{DMPGE}_{2}$ & $0.71 \pm 0.42$ & $0.005 \pm 0.003$ & $0.253 \pm 0.380$ & $7.9 \pm 1.8$ & $0.055 \pm 0.010$ & $10.5 \pm 2.2$ \\
\hline Triacitin & 0.0 & 0.0 & 0.0 & $3.9 \pm 0.8$ & $0.034 \pm 0.003$ & $4.9 \pm 0.4$ \\
\hline$p$ value & $<0.01$ & $<0.005$ & NS & $<0.005$ & $<0.005$ & $<0.005$ \\
\hline
\end{tabular}

* Degrees of freedom were 8 except for sucrase specific activity/mg DNA where degrees of freedom were 7 .

Table 6. Blood corticosterone levels and disaccharidase activities in sham-operated and adrenalectomized suckling rats after enteral 16,16-DMPGE $E_{2}$ vs vehicle administration; rats were sacrificed on day 15 of life $(\bar{X} \pm S D)$

\begin{tabular}{|c|c|c|c|c|c|}
\hline \multirow[b]{2}{*}{ Treatment } & \multirow[b]{2}{*}{$\begin{array}{c}\text { Corticosterone } \\
(\mathrm{ng} / \mathrm{ml})\end{array}$} & \multicolumn{2}{|c|}{ Sucrase } & \multicolumn{2}{|c|}{ Maltase } \\
\hline & & $\begin{array}{l}\text { Total } \\
\text { units }\end{array}$ & $\begin{array}{l}\text { Specific activity } \\
\text { per mg protein }\end{array}$ & Total units & $\begin{array}{c}\text { Specific activity } \\
\text { per mg protein }\end{array}$ \\
\hline $\begin{array}{l}\text { Sham } \\
\text { PGE (4) }\end{array}$ & $30.80 \pm 16.57$ & $6.8 \pm 2.5^{*}$ & $0.040 \pm 0.020 \dagger$ & $22.8 \pm 5.2^{*}$ & $0.135 \pm 0.050$ \\
\hline $\begin{array}{l}\text { Sham } \\
\text { Triacitin (4) }\end{array}$ & $38.48 \pm 28.36$ & $2.3 \pm 1.4$ & $0.017 \pm 0.014$ & $7.1 \pm 3.5$ & $0.046 \pm 0.009$ \\
\hline $\begin{array}{l}\text { Adrenalectomized } \\
\text { PGE (5) }\end{array}$ & $5.36 \pm 4.05$ & $1.8 \pm 1.6 \dagger$ & $0.015 \pm 0.014^{*}$ & $7.1 \pm 4.1$ & $0.055 \pm 0.030$ \\
\hline $\begin{array}{l}\text { Adrenalectomized } \\
\text { Triacitin (7) }\end{array}$ & $3.31 \pm 3.36$ & $0.5 \pm 0.2$ & $0.004 \pm 0.001$ & $4.3 \pm 1.2$ & $0.037 \pm 0.060 \S$ \\
\hline
\end{tabular}

Numbers in parentheses indicate numbers of rats.

The mean \pm SD corticosterone levels for the sham-operated animals was $34.64 \pm 21.89$, and for the adrenalectomized animals was $4.16 \pm 3.64$ $(p<0.001$ by two-tailed $t$ test). No significant differences were seen in corticosterone levels between animals given PGE or Triacitin within the adrenalectomized or sham-operated groups.

$p$, values for PGE groups versus respective triacitin control groups ${ }^{*} p<0.01 ; \dagger p<0.05 ; \ddagger p<0.025 ; \S p=0.009$. 
but may be related to increased protein synthesis, which is supported by the increased ${ }^{3} \mathrm{H}$-leucine incorporation into brush border membrane protein. When 16,16-DMPGE ${ }_{2}$ was administered enterally, sucrase and maltase activities were increased in intact sham-operated and adrenalectomized rats suggesting that the adrenal-intestinal axis is not necessary for this effect.

The effects of glucocorticoids on small intestine in developing mammals have been described in numerous investigations $(2,4$, $5,17-21)$. These effects are thought to be associated with biochemical maturation of the absorptive capabilities of mammalian small intestine which are dependent on disaccharidase activities. A glucocorticoid-sensitive period has been described for jejunal sucrase in rats that occurs just before and coincident with the appearance of the enzyme (14-17 days) (22). Data from previous investigations have suggested that similar effects may follow subcutaneous administration of $\mathrm{PGI}_{2}$ or subcutaneous implan-

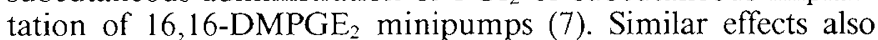
have been seen after enteral administration of 16,16-DMPGE 2 by gavage to suckling but not adult rats (8).

In adult rats, prostaglandins are known to influence many aspects of gastrointestinal function, including motility, secretion, mucosal blood flow, mucus production, and ulcer formation (23). Both $\mathrm{PGE}_{2}$ and lesser amounts of prostaglandin $F$ are present in the gastrointestinal tract (24). $\mathrm{PGI}_{2}$ is also found in the rat stomach (25). It has gastric antisecretory and cytoprotective properties similar to those of $\mathrm{PGE}_{2}$ (26). Robert et al. (26, 27 ) have shown that prostaglandins may have a "cytoprotective" effect on the gastrointestinal tract and speculate that they may protect the small intestinal mucosa from luminal insults by regulating mucus secretion. Lichtenberger et al. (28) have demonstrated that this protective effect may be partially related to an increased surfactant-like material coating the surface of the intestinal tract.

Since exogenously administered prostaglandins cause somewhat similar effects to those of the glucocorticoids, it is apparent from our studies that these compounds may also relate to small intestinal metabolic processes during development. Our data suggest that the disaccharidase stimulatory effect is not dependent on the presence of the adrenal glands, and therefore the prostaglandins do not act through the adrenal-intestinal axis. Several possibilities could explain the mechanism of the prostaglandin stimulation effect on the disaccharidases. Another "second messenger," such as cyclic AMP (29), could be an important mediator of this prostaglandin-initiated stimulation of disaccharidase activities. On the other hand, this stimulation could be a direct effect of the prostaglandins themselves. Another possibility is that the positive surfactant barrier secreted by the enterocyte in response to prostaglandin administration (28) may protect these brush border membrane-bound enzymes from proteolysis by luminal proteases. These are known to hydrolyze intestinal brush border disaccharidases as demonstrated in previous studies in pancreatic-deficient animals (30). Further studies are required to elucidate the mechanism of this prostaglandin-initiated stimulation of disaccharidase activity in the mammalian small intestine.

\section{REFERENCES}

1. Deren JJ 1968 Development of intestinal structure and function. In: Code CF (ed) Handbook of Physiology. Vol 3. Sect 6. American Physiological Society. Washington. DC. pp 1099-1123

2. Moog F 1971 Corticoids and the enzymatic maturation of the intestinal surface: alkaline phosphatase, leucyl-naphthylamidase and sucrase. In: Hamburgh
M, Barrington EJW (eds) Hormones in Development, Meridith, New York, pp $143-160$

3. Henning SJ, Kretchmer N 1973 Development of intestinal function in mammals. Enzyme 15:3-23

4. Doell RG, Kretchmer N 1964 Intestinal invertase: precocious development of activity after injection of hydrocortisone. Science 143:42-44

5. Koldovsky O, Jumawan J, Palmieri M 1975 Effect of thyroidectomy on the activity of $\alpha$-glucosidases and acid hydrolases in the small intestine of rats during weaning. $J$ Endocrinol $66: 31-36$

6. Deren JJ, Broitman SA, Zamcheck N 1967 Effect of diet upon intestinal disaccharidase and disaccharide absorption. J Clin Invest 46:186-195

7. Neu J, Hoffman RG, Crim WN 1983 Prostaglandin-mediated effects on growth and markers of biochemical development in the rat. Pediatr Res 17:537-540

8. Koelz HR, Lentze MJ, Muller O, Halter F 1984 16,16-dimethyl prostaglandin $\mathrm{E}_{2}$ (PGE) stimulates the activities of intestinal brush border enzymes in suckling rats. Gastroenterology 84(pt2): 1210 (abstr)

9. Tsuboi KK, Schwartz SM, Burrill PH, Kwong LK, Sunshine P 1979 Sugar hydrolases of the infant rat intestine and their arrangement on the brush border membrane. Biochim Biophys Acta 554:234-248

10. Lowry OH, Rosebrough NJ, Farr AL, Randall RJ 1951 Protein measurement with folin phenol reagent. J Biol Chem 193:265-275

11. Burton K 1956 A study of the conditions and mechanisms of the diphenylamine reaction for the colorimetric estimation of deoxyribonucleic acid. Biochem J 62:315-323

12. Munro HN, Fleck A 1966 In: Methods in Biochemical Analysis, vol 14. Interscience. New York, pp 113-176

13. Corticosterone Systems Laboratories, Inc Jan 1984 Corticosterone $\left(\mathrm{H}^{3}\right) \mathrm{Kit}$. Procedure for the radioimmunoassay of rat serum or plasma corticosterone. Carson, CA. Catalog no 301

14. Schmitz J, Preiser H, Maestracci D, Gosh BK, Cerda JJ, Crane RK 1973 Purification of the human intestinal brush border membrane. Biochim Biophys Acta 323:90-112

15. Johnson LR. Guthrie P 1976 Mucosal DNA synthesis: effect of cholecystokinin and 16,16-dimethyl prostaglandin $E_{2}$ on RNA and DNA of gastric and duodenal mucosa. Gastroenterology 70:59-65

16. Tsuboi KK, Kwong KL, Neu J, Sunshine P 1981 A proposed mechanism of normal intestinal lactase decline in the post-weaned mammal. Biochem Biophys Res Commun 101:645-652

17. Rubino A, Zimbalatti F, Auricchio S 1964 Intestinal disaccharidase activities in adult and suckling rats. Biochim Biophys Acta 92:305-311

18. Herbst JJ, Koldovsky O 1972 Cell migration and cortisone induction of sucrase activity in jejunum and ileum. Biochem $\mathrm{J}$ 126:471-476

19. Lebenthal E. Sunshine P, Kretchmer N 1972 Effect of carbohydrate and corticoids on activity of $\alpha$-glucosidases in intestine of the infant rat. J Clin Invest 51:1244-1250

20. Henning SJ, Helman TA, Kretchmer N 1975 Studies on normal and precocious appearance of jejunal sucrase in suckling rats. Biol Neonate 26:249-262

21. Yeh K, Moog F 1975 Development of small intestine in the hypophysectomized rat. II. Influence of cortisone, thyroxine, growth hormone and prolactin. Dev Biol 47:173-184

22. Henning SJ, Sims JM 1979 Delineation of to clucocorticoid-sensitive period of intestinal development in the rat. Endocrinology 104:1158-1163

23. Bennett A, Fleshler B 1970 Prostaglandins and the gastrointestinal tract. Gastroenterology 59:790-800

24. Bennett A, Murray JG, Wyllie JH 1968 Occurrence of $\mathrm{PGE}_{2}$ in the human stomach and a study of its effects on human isolated gastric muscle. $\mathrm{Br} \mathrm{J}$ Pharmacol Chemother 32:339-349

25. Pace-Asciak C, Nashat M, Menon NK 1976 Transformation of prostaglandin $\mathrm{G}_{2}$ into $6(9)$-oxy-11,15-dihydroxyprosta-7,13-dienoic acid by the rat stomach fundus. Biochim Biophys Acta 424:323-325

26. Robert A, Hanchar AJ, Lancaster C. Nezamis JE 1978 Antisecretory and cytoprotective effects of prostacyclin $\left(\mathrm{PGI}_{2}\right)$. Fed Proc 37:460(abstr)

27. Robert A 1976 Antisecretory, anticuler, cytoprotective and diarrheogenic properties of prostaglandins. In: Samuelsson B, Paoletti R (eds) Advances in Prostaglandin Thromboxane Research, Vol 2. Raven Press, New York, pp $507-520$

28. Lichtenberger L, Graziani LA. Dial EJ, Butler BD, Hills BA 1983 Role of surface-active phospholipids in gastric cytoprotection. Science 219:13271329

29. Schwartz CJ, Kimberg DV, Ware P 1975 Adenylate cyclase in intestinal crypt and villus cells: stimulation by cholera enterotoxin and prostaglandin $E_{1}$. Gastroenterology 68:94-104

30. Alpers DH, Tedesco FJ 1975 The possible role of pancreatic proteases in the turnover of intestinal brush border protein. Biochim Biophys Acta 401:2840 